This item was submitted to Loughborough's Research Repository by the author.

Items in Figshare are protected by copyright, with all rights reserved, unless otherwise indicated.

\title{
Representing the victorious past: Chinese revolutionary TV drama between propaganda and marketization
}

PLEASE CITE THE PUBLISHED VERSION

https://doi.org/10.1177/01634437211022721

PUBLISHER

SAGE Publications

VERSION

AM (Accepted Manuscript)

\section{PUBLISHER STATEMENT}

This paper was accepted for publication in the journal Media, Culture and Society and the definitive published version is available at https://doi.org/10.1177/01634437211022721. Users who receive access to an article through a repository are reminded that the article is protected by copyright and reuse is restricted to noncommercial and no derivative uses. Users may also download and save a local copy of an article accessed in an institutional repository for the user's personal reference.

\section{LICENCE}

CC BY-NC-ND 4.0

\section{REPOSITORY RECORD}

Wang, Yingzi, and Thoralf Klein. 2021. "Representing the Victorious Past: Chinese Revolutionary TV Drama Between Propaganda and Marketization”. Loughborough University. https://hdl.handle.net/2134/14680113.v1. 


\title{
Representing the Victorious Past: Chinese Revolutionary TV Drama \\ between Propaganda and Marketization
}

\author{
Yingzi Wang \\ Nanjing Normal University, China \\ Thoralf Klein \\ Loughborough University, UK
}

\begin{abstract}
This paper examines the changes and continuities in TV representations of Chinese Communist Party's revolutionary history and interprets them within the broader context of China's political, economic and cultural transformations since the 1990s. Drawing on a comparative analysis of three state-sponsored TV dramas produced between the late 1990s and mid-2010s, it traces how the state-sanctioned revolutionary narratives have changed over time in response to the Party's propaganda imperatives on the one hand, and to the market-oriented production environment on the other. The paper argues that while TV productions in the new century have made increasing concessions to audience taste by adopting visually stimulating depictions and introducing fictional characters as points of identification for the audience, the revolutionary narratives were still aligned
\end{abstract}


with the Party's propaganda agenda at different times. This shows the ongoing competition between ideological and commercial interests in Chinese TV production during the era of market reforms.

\section{Keywords}

CCP, revolution, TV drama, propaganda, marketization, China, television

\section{Introduction}

Chinese television dramas reflecting the revolutionary history of Chinese Communist Party (CCP) began to burgeon from the early 1980s and have developed into a unique genre in recent decades. Mostly set against the background of the Anti-Japanese War (1937-1945) and the Civil War (1946-1949) between the CCP and the Guomindang (Chinese National Party, hereafter referred to as GMD), these TV programs retell the CCP's struggles in the revolutionary wars through depictions of heroic Communists. Such depictions form part of a politically important category called 'significant themes in revolutionary history' (zhongda geming lishi ticai), which presents the historical merits of CCP leaders (e.g. Mao Zedong, Zhou Enlai) and milestone events marking the Communist achievements in the war. Sponsored by the propaganda organs of the Party- 
state, this genre aims to provide a hegemonic reading of CCP revolutionary history for Chinese audiences.

Yet, the importance of this genre is by no means limited to giving the audience an opportunity to commemorate Communist leaders and historical events. As noted by Schwartz (1982: 395), "while the object of commemoration is usually to be found in the past, the issue which motivates its selection and shaping is always to be found among the concerns of the present'. Chinese TV dramas addressing the 'significant themes' are expected to propagate the Party's 'glorious revolutionary history' on the one hand, and to educate contemporary audiences on the other (Wen, 1992). With the popularity of television among Chinese households since the 1990s, TV dramas have increasingly become a means of mass entertainment by providing a life experience focused on family stories and individual emotions (Yin and Yang, 2004). The implementation of a market economy since 1992 has further pushed the revolutionary themes to adopt narrative strategies favored by audiences. TV producers of the 'significant themes' therefore need to strike a fine balance between following the Party's propaganda imperatives and satisfying popular interest.

At the same time, the political authorities have stepped up to promote revolutionthemed dramas: as well as giving political guidance and allocating resources necessary for production, the Party-state provides full funds for producing 'significant themes' and often invites the General Secretary to write a calligraphy for the title of dramas 
(Yang, 1997). According to a recent study (Wang, 2019), the airing of revolutionary dramas on China Central Television (CCTV) saw an overall increase between 1992 and 2017, accounting for the second highest percentage (22.13\%) of all dramas shown on this TV channel - with the highest scored by dramas with romantic themes $(36.06 \%)$. This suggests that revolutionary themes are competing with romantic TV dramas, a genre generally favored by the audience. Yet it remains to be investigated how revolutionary TV dramas themselves have changed in content and style within the evolving landscape of political, economic and cultural requirements.

Existing literature on this issue has fully recognized the integration of popular narrative forms within the reconstruction of CCP revolutionary history. Zhang (2009) notes the increasing use of audio-visual effects, particularly explosion, smoke and fire, in making state-sponsored 'war epics'. With regard to the depiction of Communist leaders, Zhou and Ouyang (2019) highlight the narrative turn towards the emotional side of the political and military figures, as well as the increasing amount of fictional content in characterizing their personalities. Studies on revolution-themed TV fiction (e.g. Qian, 2008) identify two main strategies to popularize the narrative: humanizing both the Communist heroes and their enemies, and romanticizing gender relationships. While the above analyses have mapped out key changes in the aesthetics of the revolutionary dramas, they seldom provide a systematic account of why their forms and uses have changed over time, let alone connecting the aesthetic changes to the wider 
socio-political context. In this article, we aim to address this gap by applying a longitudinal section and comparing three state-sponsored 'significant-theme' TV dramas recounting the revolutionary past. We argue that the retelling of CCP revolutionary history is closely tied to the CCP's respective propagandistic agenda at the time of production, while also making concessions to audience tastes by introducing narrative elements closer to viewers' lived experiences. This shows both the continuity of Chinese television's propaganda functions and the forceful impact of marketization in the media sector.

The article is divided into two parts: first, we reflect on the persistent importance of CCP revolutionary history in the reform period and key changes in China's media and cultural context over the last three decades. Second, we conduct a comparative qualitative analysis of three TV dramas produced between late 1990s and mid-2010s. In so doing, we trace major changes in the depiction of revolutionary characters and events, while also paying attention to continuities, and interpret them with reference to the broader political, economic and cultural transformation.

\section{The Enduring Significance of the Revolutionary Legacy}

The CCP's revolutionary history dates back to the early 1920s, when the Party was founded in times of social unrest. In the early years, the size and influence of CCP were 
small compared to the GMD, which ruled the Republic of China (ROC) between 1927 and 1949. Historians (e.g. Mühlhahn, 2019: 318-325) generally believe that it was not until the Anti-Japanese War that the CCP gained momentum and strengthened its power base. This was largely enabled by the Second United Front with the GMD, which gave the CCP a much-needed official status and legitimized its wartime mobilization. This alliance, lasting from 1937 to (effectively) 1941, was rather loose. Although the Communist army was officially integrated into the GMD's National Revolutionary Army, both sides pursued different strategies in resisting the Japanese. The Nationalist Army mainly fought a conventional and symmetric war, bearing the brunt of the Japanese attack and eventually stemming the Japanese advance at the war front, while the Communists engaged in guerrilla warfare from base areas in northern China. The Japanese surrender in September 1945 did not bring lasting peace to China. In 1946, Nationalists and Communists resumed their civil war, which had been temporarily halted by the Japanese invasion. The four years of war culminated in the Communist triumph, the proclamation of the PRC on 1 October 1949 and the retreat of GMD troops to Taiwan, which was completed two months later. In mainland China, the revolution from 1945 to 1949 is called the 'War of Liberation' (Jiefang zhanzheng).

In the official memory of the PRC, both the Anti-Japanese War and the Civil War are viewed as integral episodes of the Communist revolution (on the memory of the Anti-Japanese War, see most recently Mitter, 2020). The revolution constitutes the basis 
of the CCP's legitimacy to rule. In the official discourse, especially since the 1990s, the century between 1839 and 1949 has been referred to as a 'century of national humiliation' (bai nian guochi) characterized by subservience to Western imperialism. The CCP's claim of having founded a new, independent China in 1949 allowed the Party to present itself as 'the defender of the Chinese nation-state and China's national interest' (Collins and Cottey, 2018: 37). This was important as at the beginning of Communist rule, the Party had neither a ready-made concept for changing China, nor was its hold over the country secure and could only be realized through a coalition of workers, peasants, the petty bourgeoisie and the national bourgeoisie (Mühlhahn, 2019: 359-374).

In the long run, however, the CCP could not base its legitimacy solely on its revolutionary credentials. Each generation of leaders has had to search for new sources of legitimacy while carefully crafting its official ideological line with reference to the revolutionary legacy (Zhao, 2011). The initial emphasis of Mao Zedong on class struggle had led to economic stagnation and political turmoil by the end of the 1970s, which forced the new leadership, headed by Deng Xiaoping, to take action to restore public confidence in CCP rule. Economic reforms and the opening to global capitalism became the remedy. The adoption of a 'socialist market economy' (officially in 1992) greatly boosted economic growth but was thought to have 'weakened the CCP's moral capital' due to the proliferation of capitalist modes of production (Guo, 2003: 13). In 
order to counter this trend, Deng reiterated China's adherence to the socialist path and propagated the concept of a 'socialism with Chinese characteristics' to back up his strategy of market reform.

The acceleration of market reforms in the 1990s pushed Deng's successor Jiang Zemin (the paramount leader between 1989 and 2002) into addressing the pressing issue of integrating the private sector with the socialist market economy, as well as the legal status of new social groups that emerged (especially private entrepreneurs). In 2000, Jiang proclaimed the 'Three Represents', declaring that the CCP must represent 'the fundamental interests of the overwhelming majority of the Chinese people' (Jiang, 2002: 583). This theory is seen as a practical measure to broaden the Party's social support, particularly from private entrepreneurs who could now become Party members, while boosting the Party's image as a party of all the people (Guo, 2003: 16). A few years later, in order to further address the social and economic inequalities resulting from market reforms (e.g. widening regional disparities), Hu Jintao, the CCP General Secretary from 2002 to 2012, introduced new political doctrines such as the 'scientific outlook on development'. According to Zhao (2011: 206), the articulation of 'sustainable development' was clothed in the language of 'scientific socialism', which demonstrated Hu's eagerness to 'reconnect with the revolutionary tradition'.

Alongside the re-adjustment of Party ruling doctrines, there have been continuing efforts to promote patriotism and nationalism since the early 1990s. The Party-state 
launched various propaganda campaigns for patriotic education to reinforce the idea that upholding CCP leadership lies at the heart of patriotism (Brady, 2008: 50). These campaigns included holding national commemorative events for the anniversaries of the founding of the PRC, with the revolutionary war being a recurrent theme of these events. The patriotic education movement and the nationalist appeals reached a climax during Xi Jinping's term of office (2012-present). In late 2012, the new paramount leader first mentioned his ideal of the 'Chinese dream', which entailed the goal of achieving the 'great rejuvenation of the Chinese nation' (Xinhua, 2012). This political vision connects the fulfilment of individual dreams to the prerequisite of achieving the collective national dream (Gow, 2017). Furthermore, Xi has sought to create common historical memories with Taiwan by interpreting the Anti-Japanese War as a tragedy for all 'Chinese compatriots', so as to enhance a common national identity across the Taiwan Strait (Lin and Wu, 2017: 80-81). Expressing nationalist sentiments can be an effective means of creating social unity and cohesion (Brady, 2008: 49). As Pickering (2001) observes, nationalist discourse operates through ideas of social inclusion and exclusion, especially through the discursive deployment of 'Others': by constructing a negative 'Other', it is possible to unify the positive 'Self'. The war fought between the Japanese invaders and Chinese resistance forces appeared particularly suitable for national identification in this context. 
Evidently, the purposive uses of the revolutionary legacy have been an integral part of the CCP's ideological legitimation strategy, particularly in the reform era. Whenever the market reforms reached a stage where social conflicts emerged and threatened to undermine the CCP's leadership, doctrines and events from the revolutionary past would be drawn on to boost public confidence in CCP rule. As we show in the following section, China's state-run television has been an indispensable part of the Party-state's propaganda campaigns and an important site of reconstructing the revolutionary memory. Even so, the state-promoted revolutionary narratives have needed to adapt to the market-oriented production context.

\section{Marketization and Chinese Television Production}

The profound political and economic transformations in China over the past few decades have been paralleled by changes to the media system. The media system, which is controlled by the $\mathrm{CCP}$, has long been perceived as a propaganda tool in the hands of the Party-state. In the early PRC period, 'propagating politics' (xuanchuan zhengzhi) was emphasized as the first priority of all media, particularly of TV broadcasting (Guo, 2005: 238). But this situation began to change alongside the shifting focus in the Party's propaganda work from class struggle to economic development and in tandem with the commercial reforms within the media system initiated since 1978. Several central media 
organizations have since been encouraged to operate as commercial organizations, for instance by generating revenue through advertising fees. From 1992 onwards, market forces quickly transformed the media system. Chinese television, while being redefined as part of a tertiary industry, became increasingly reliant on market-based financing and driven by ratings.

At the same time, the context of Chinese TV production was influenced by international cultural trends. As Turner (2010) notes, the media industries' commercial strategy, which turns information into entertainment, has resulted in an overwhelming global trend towards entertainment. The shift of Chinese television towards entertainment has become prominent since the late 1990s (Bai, 2005) and has further intensified since China's admission to the World Trade Organization in 2001, which led to an increase of international contacts, economic and otherwise. In particular, Chinese TV producers have increasingly drawn on commercially successful narrative strategies from Hollywood films to attract domestic audiences (Ma, 2014). Even so, the increasingly fragmented audience in the digital era has posed new challenges for TV producers. As Gray and Bell (2013: 10) show with regard to the UK, the proliferation of specialized TV channels, facilitated by digital technology, has resulted in the 'breaking up of the large national audience associated with terrestrial television'. This is also true of China: Keane (2015) finds that most Chinese audiences, especially the younger generation, nowadays enjoy online binge-watching, whereas fewer continue to look at 
television screens. Consequently, Chinese TV producers have started searching for 'niche' audiences and carefully tailoring content to the assumed preferences of these target audiences.

On the face of it, political control over the Chinese television system has loosened as a consequence of the marketization process. However, this is only partially true. The Party-state has taken active measures to restructure media institutions since the late 1990s, so as to ensure that commercial operations do not affect the propaganda role of key media outlets. Particularly, state-run TV stations have been instructed to 'separate production from broadcasting' (zhi bo fenli), meaning that they can delegate the production of non-news programs, including TV dramas and entertainment shows, to newly founded independent production companies. This is to maximize the profit of Chinese television stations through entertainment programming while at the same time maintaining ideological conformity in news broadcasting.

Additionally, the Party-state has actively engaged in cultural propaganda by utilizing popular media forms to deliver its political messages. The aforementioned 'significant themes in revolutionary history' are a case in point. This revolutionary theme emerged in the late 1970s, when people started commemorating the political leaders who had died in the Cultural Revolution (1966-1976). TV plays recounting the revolutionary lives of Communist leaders gained momentum from the mid-1980s, a prominent example being The Death of Qiubai (Qiubai zhi si, 1987), which focuses on an early 
head of the Party. In order to better regulate the production of works with 'significant themes', in 1987 the Central Propaganda Department formed a leading group comprised of officials and experts with knowledge of not only Party and military history but also film and television production. The group was tasked with reviewing scripts and, before broadcasting, the complete works (Tang and He, 2014: 7). Revolution-themed productions have designated distribution channels, such as CCTV-1, the flagship TV channel of CCTV. Ever since television became the most popular medium among the Chinese population in the 1990s, TV dramas with 'significant themes' have been aired regularly during evening prime time on CCTV-1. Moreover, government awards are frequently given to these dramas as a gesture of state approval.

The systemic changes brought about by marketization were also reflected in the production of state-sponsored revolutionary dramas. At a 2005 symposium on developing TV series with 'significant themes', officials and experts from the Party's Central Propaganda Department and the State Administration of Radio, Film and Television (SARFT) advised TV producers to balance the economic and social effects of revolutionary dramas and proposed to allow more private companies to join the production of this genre. Previously, only a few state-run production units (e.g. those affiliated to the central and provincial TV stations) were permitted to produce this genre. The move hence encouraged the incorporation of commercially successful models and narrative strategies into the grand revolutionary theme and granted more 
creative freedom to Chinese TV producers. Under these conditions, the hegemonic reading of revolutionary history as prescribed by the Party-state was adapted to the preferences of contemporary Chinese audiences, becoming part of the cultural and entertainment industry (Zhang, 2009). Therefore, the analysis of the changing nature of revolutionary narratives must address the 'ambiguous and paradoxical process' of Chinese media transformation, which entails the increasing application of market strategies on the one hand and the intensified (re)articulation of China's socialist legacies on the other (Sun and Zhao, 2009: 98).

In the remainder of this article, we adopt a qualitative comparative method, analyzing three state-sponsored revolutionary dramas aired on CCTV-1. Each drama was created in response to state celebrations which marked the historical and political achievements of the CCP. The first is War of China's Fate (Zhongguo mingyun de juezhan), broadcast in October 1999 to echo the fifty-year anniversary of the founding of the PRC. ${ }^{1}$ The second drama, Eighth Route Army (Balujun), aired in August 2005, corresponding with the sixtieth anniversary of China's victory in the Anti-Japanese War. The third, On Taihang Mountain (Taihangshan shang), was broadcast in 2015, also to commemorate China's victory in the war against Japan. The three dramas depict the military conflicts between the CCP, GMD and the Japanese armies from 1937 to 1949 , with the narrative primarily focused on the CCP leadership in the war. The production time of these programs spanned the period from the late 1990s to mid-2010s, 
corresponding to different political contexts and media changes. A diachronic comparison between them enables us to identify changes and continuities in the televised representations of revolutionary war. We focus on key narrative elements regarding main characters and plots, in conjunction with production information. In so doing, our interpretation is to link the findings to the changing political, economic and cultural contexts.

\section{War of China's Fate: 'Only the CCP Can Save China'}

War of China's Fate is a thirty-episode serial drama produced by China Television Production Centre (CTPC), a drama production unit affiliated to CCTV. Set during the 'War of Liberation' from August 1945 to October 1949, the drama revolves around the question of who - CCP or GMD - will legitimately rule China after the Japanese invaders have withdrawn from the country. The plot takes the US intervention to support the GMD in establishing a democratic government as its starting point and then focuses on how Mao Zedong and Zhou Enlai resist GMD suppression and unite various national democrats to subvert the Nationalist government led by Chiang Kai-shek. For providing solid (narrated) evidence for the ruling legitimacy of the CCP, this TV show won official recognition and the government-sponsored Feitian Award in 2001. 
The endeavor to affirm the CCP's ideological legitimacy is mostly demonstrated through binary oppositions in the portrayal of key political leaders, identified as either heroes or villains, peace-loving or war-mongering. The heroes are Mao Zedong and Zhou Enlai, representing the good side and aiming for peaceful negotiations. They are portrayed as righteous and optimistic, fighting for democratic rule while opposing Chiang Kai-shek's dictatorship and persecution of democrats. By contrast, Chiang Kaishek, the main villain, is depicted as a grumpy and selfish dictator. He constantly violates the agreements between different political parties and rejects any cooperation with the CCP. While defeated by the CCP in battle, Chiang sends more troops to the frontline instead of seeking peace talks, and speeds up his efforts to make a fortune from the war.

The contrast between the two camps is enhanced further with the aid of visual techniques, including different camera angles, lighting colors and background settings. Low-angle shots are often used for the Communist leaders, making them appear taller and thus underscoring their power and energy. The lighting in these shots is bright and warm, reinforcing the positive image of Mao and his entourage. Whenever Chiang appears, the background is suffused with cold lighting, highlighting the image of the Nationalist leader as a violent and bad-tempered dictator. Contrasting surroundings and props provide further details to reveal the class differences represented by the two parties, as well as to indicate the two different pathways open to China at the time. In a 
sequence of meetings of both party leaderships cut into one another, Chiang's presidential palace is equipped with classical-style, upscale mahogany furniture, whereas the CCP's meeting room is in a randomly picked cave house filled with desks and chairs of a mixed style. These parallel shots imply that Chiang and his government rule in the interest of China's wealthy bourgeoisie, not the population at large. By contrast, the Communist leaders share the life of villagers and borrow their houses as temporary headquarters, suggesting that they represent the interests of ordinary people. As the director of this drama emphasizes, the contrast in lighting and images was designed to envision 'a glorious future' for the CCP leadership and a preordained failure of GMD rule over China (Wang, 1999). Even before this was officially enshrined in Jiang's Three Represents, the visual contrast in War of China's Fate thus underscores the CCP's claim to political legitimacy by representing the broad masses of the population.

The political climate in the mid-1990s may provide insights into the contrasting representations of the Nationalist and Communist parties. The propaganda of the $\mathrm{CCP}$ at the time was informed by a number of events which were perceived as threatening China's national unity and stability. The most high-profile among them included the 1995-1996 Taiwan Strait Crisis and the 'China Threat' rhetoric disseminated in the US, both of which let the senior leadership of China believe that the US was attempting to weaken China. In reaction to these perceived challenges, Jiang Zemin stressed the 
importance of ideological work, requiring media practitioners to guide public opinion towards accepting the leadership of the CCP (Brady, 2008: 51). An essential part of this work was to strengthen patriotic education in the propaganda and cultural spheres. The director of War of China's Fate claims that the significance of the drama was to prompt thinking about US-China relations from the perspective of international politics (Wang, 1999). The increasing confrontation between the incumbent president of Taiwan and GMD leader, Li Denghui, and the CCP on the matter of China's unification at the time, together with the US intervention in the Strait Crisis, provided a background for portraying the antagonistic political camps in the TV drama. Also, in the context of celebrating the Communist victory in the 'War of Liberation', it was deemed politically correct to cast the GMD as an evil enemy to national unity.

The construction of nationalist discourse is often based on creating a sense of national belonging. To this end, War of China's Fate employs a voice-over narrator to align viewers with the Communist cause. From the first episode, the voice-over takes the side of the CCP and identifies it as 'our Party' (wo dang). After each battle, the voice-over summarizes the achievements of 'our army' (wo jun) and the losses of the GMD army. Through the binary construction of the victorious 'our Party' as opposed to the incompetent GMD, the audience can easily align themselves with the $\mathrm{CCP}$ as the embodiment of the 'national Self'. This mode of national identification was in line with 
the propaganda campaigns of the 1990s, which aimed to reinforce people's loyalty to the Party-state.

With regard to aesthetic expression, War of China's Fate borrows historical footage to present battle scenes and combines it with the typecasting of actors who look exactly like the historical figures to create a sense of historical authenticity. The production team explained that they received an instruction from the director of CCTV to make a TV series reflecting the development of political strategies by both the CCP and GMD, so they decided to place more emphasis on representing political negotiations and use archival footage for the limited amount of war scenes (Tong, 1999). Because of this strategy, however, the drama is mainly formed of didactic conversations filled with political slogans. Judged by today's standards, this narrative form seems repetitive, dull, and lacks intriguing development in characterization or plot. Given that the drama was produced between 1996 and 1998, when mass entertainment culture had just emerged in China and popular preferences were still taking shape, it is no surprise that this propaganda drama did not necessarily satisfy the taste of the audience. Compared to War of China's Fate, our second case, Eighth Route Army, which was made six years later, demonstrates greater skills in using new narrative devices. 


\section{Eighth Route Army: 'Putting the People First'}

At the outbreak of the Anti-Japanese War in 1937, the CCP's Red Army was formally incorporated into the Nationalist Army, changing its name to Eighth Route Army while in practice still being led by the CCP. The 2005 serial drama Eighth Route Army retells the developments of this period. Jointly produced by CCTV, the Propaganda Department of the Shanxi Provincial Party Committee, and August First Film Studio, this TV series garnered not only government-sponsored awards, but also a Jinying Award, which is based on audience votes. This result indicates a more favorable audience reception of this production than of similar ones previously. It therefore provides insights into both the evolution of narrative techniques and the political and cultural context of the mid-2000s.

The narrative mainly focuses on how the CCP leader, Mao Zedong, and General Zhu De lead the Eighth Route Army and the Chinese nation to final victory over Japan, although historically both the CCP and GMD took part in fighting the Japanese. Particularly, the 'mass line' (qunzhong luxian) developed by Mao Zedong, together with his call for 'relying on the people', is praised throughout the narrative. This policy was historically one of the political and organizational principles of the CCP, which included listening to the masses and feeding back decisions to them (Schram, 1989: 9798). Despite moving away from the basic emphasis on the mass line, Eighth Route Army 
conveys the idea that mobilizing the people and constructing a powerful united front which included the GMD - were the CCP's key strategies to win the Anti-Japanese War.

As the aim of the drama was to highlight the strength of united-front politics, the binary treatment of good CCP and evil GMD, which underpinned War of China's Fate, was no longer appropriate. More inclusive depictions of the GMD characters, including both real historical figures and fictional characters, drive the plot. For instance, Wei Lihuang, a GMD general who was historically an enemy of the CCP's Red Army in the first phase of the civil war (1927-1936) and also appears in War of China's Fate on the enemy side, is portrayed positively in Eighth Route Army. In the fourth episode, after the Communist army has attacked a Japanese military airfield and thereby greatly relieved the pressure on the GMD's battlefront, Wei feels extremely grateful, becomes an admirer of the CCP's military strategy and trustfully cooperates with the Communists. Likewise, some of the fictional characters, such as a GMD war correspondent, also show a positive attitude towards the Communist side. The journalist initially works for the GMD, but subsequently decides to join the CCP out of admiration for the Communist policy of 'putting the people first' - a slogan in line with Jiang Zemin's Three Represents. In these cases, the GMD characters are no longer portrayed as a hostile 'Other' but depicted as members of the 'national Self'. This signifies a return to the depictions of the GMD in the 1980s and early 1990s, when several Chinese 
war films (e.g. The Bloody Battle of Tai'erzhuang - Xue zhan Tai'erzhuang, 1986) showed the Nationalist Army's fight against the Japanese army in a positive light. It was only between the mid-1990s and early 2000s that, due to the rising tensions across the Taiwan Strait, films with a similar tendency were prohibited by the Communist authorities. $^{2}$

This does not mean the GMD, despite being positive, is equal to the CCP in these productions. Nationalist characters in Eighth Route Army are frequently placed in an inferior position to the CCP leaders. For example, they need the support and guidance of the CCP in every frontline battle their army participates in. This narrative strategy still places the CCP as the only force that represents the interests of 'our people' and 'our nation' and thus as the only political side that can legitimately rule China.

The emphasis on representation of the broad masses and the more positive depiction of the GMD were in line with the new focus of CCP propaganda in the early 2000s. In order to address the ideological contradictions resulting from the implementation of the 'socialist market economy', the Party leadership introduced the doctrine of the Three Represents, which affirms the CCP's claim of representing the fundamental interests of the majority of Chinese people. In this sense, Jiang Zemin's new doctrine can be seen as a continuation of the mass line (Xiong, 2013). After the promulgation of this ideological guideline in 2002, national TV broadcasters were required to abide by the principles of the Three Represents in their programming during the following years (China 
Broadcasting and Television Yearbook, 2003: 5). Given that Eighth Route Army was produced in 2004, it is reasonable to link its emphasis on the mass line, which entails representing and fighting for the interest of the Chinese people, to the wider political context at the time of production. With regard to defining the Chinese people, all patriotic Chinese, regardless of party affiliation, can be considered as belonging to the 'national Self', so long as they accept the leadership of the CCP.

While the changes in character positioning are prominent, new commercially driven narrative elements are also obvious. In order to enhance the viewing experience of war dramas, Chinese TV producers in the new century began to reproduce the intense battle scenes and particularly explosion effects often found in war films, aiming to create an audio-visual spectacle regardless of the costs (Zhang, 2009: 68). The producers of Eighth Route Army also believed in the importance of audio-visual techniques in attracting a big audience. Hence, they utilized various props (e.g. car wrecks, gasoline cans as debris on the battlefield), gunfire and explosions, together with handheld shooting, to give an impression of the chaos of war (Dong, 2005).

Besides, the producers attempted to connect with the audience at the emotional level. They created several fictional characters who serve as subordinates of the CCP leaders. These characters experience the war from the angle of the rank and file, which allows for sub-plots about ordinary people experiencing emotional ups and downs and, on occasion, romantic involvement. In relation to this, the CCP leaders are portrayed as 
caring for their subordinates and trying to find them girlfriends, which shows the humane side of the former. This trend echoes the guiding principle of producing 'significant themes' proposed at the 2004 National TV Drama Planning Conference, which entails that one should abide by the historical actuality of real events while exercise artistic imagination in the narration (da shi bu $x u$, xiao shi bu ju), in order to align the revolutionary narratives more closely with the lives of ordinary people $(\mathrm{Hu}$, 2004). The propaganda dramas of the mid-2000s thus exhibited new narrative features manifestly different from those made in the late 1990s, which was partially in response to the political decision for TV to become more market-oriented.

\section{On Taihang Mountain: 'Building the Strongest Wartime Base'}

Also set in the period of the Anti-Japanese War, On Taihang Mountain focuses on two CCP military leaders, Liu Bocheng and Deng Xiaoping - the commander and the political commissar of the 129th Division of the Eighth Route Army -, and recounts their revolutionary life in one of CCP's largest wartime bases, Taihang Mountain. It is hence another state-sponsored revolutionary drama featuring the fight against the Japanese. This one was produced in 2013 and broadcast in August 2015. We can thus expect some continuities in its way of retelling the revolutionary war but also further developments in its narrative strategy. 
The narrative content and form in On Taihang Mountain remain largely the same as those in the two dramas previously discussed. The drama is based around the binary depiction of good CCP leaders versus evil Japanese army generals and also employs an omniscient voice-over narrator to align the audience with the Communist camp. While it adopts a similarly fictionalized approach as Eighth Route Army, one that emphasizes the humane side of CCP leaders, On Taihang Mountain also depicts the intense personal dilemmas and moral conflicts of those exercising authority in a brutal war. Liu Bocheng is portrayed as a kind-hearted military commander who wants to achieve victory but also treasures the lives of soldiers. Chen Geng, another historically important military leader of the CCP, is depicted as struggling between fighting for his communist beliefs and taking care of his family. CCP war heroes are pictured not as fighting machines or superior god-like figures but as ordinary people, which makes the revolutionary leaders more approachable for contemporary audiences.

The united front remains another important narrative focus in this 2015 drama. This is consistent with the revolutionary story as told in Eighth Route Army and signifies the continuing efforts of constructing a national identity comprising 'patriotic' GMD forces in Chinese television representations. On the one hand, this continuation reflects the progress in the relationship between the CCP and GMD from 2005 to 2015 , based on their common ground in assessing the status of Taiwan and its relationship with the PRC. At a time when the GMD was the leading opposition party in Taiwan (between 
2000 and 2008), Beijing courted the party by elevating it to the status of a diplomatic partner. After the GMD's victory in the Taiwanese presidential election of 2008 (under the leadership of Ma Yingjiu), cross-strait relations were greatly improved. On the other hand, the idea of uniting all national patriotic forces to achieve victory conveyed in $\mathrm{On}$ Taihang Mountain timely echoes Xi Jinping's political vision of the 'great rejuvenation of the Chinese nation' since 2012. Xi's articulation of the 'Chinese dream' seeks to enhance national identification among Chinese 'compatriots' across the Taiwan Strait. As Dittmer (2006: 685) indicates, 'China's nationalism remains insistently inclusive', which is epitomized by the CCP's unification policy towards Taiwan. However, it should be emphasized that On Taihang Mountain still depicts the CCP as the leading military and political force in the resistance against Japan, despite recognizing the patriotism of the GMD.

In addition to the continuities in retelling the past, one can also notice new narrative strategies. On Taihang Mountain follows the development of Liu Bocheng's military theories on guerrilla warfare. Liu is depicted as an established military expert who still modestly studies strategy and tactics. By contrast, the portrayal of Deng Xiaoping displays different personal qualities, such as his talent for mobilization and ideological persuasion, which provide adequate political support for Liu's military leadership. The difference in characterization accords with Zhou and Ouyang's (2019) observation of 
new aesthetic styles emerging in recent TV dramas, which portray political and military leaders by focusing on their individual characteristics and personal charm.

Besides, the producers of this series created more dramatic moments to increase viewers' excitement and suspense as compared to Eight Route Army. In a scene in which Liu Bocheng's 129th Division confronts the Japanese Army, Liu almost loses his life when retreating from the battlefield. By the same token, the series features thrilling combat scenes, including gun battles between the Communists and the Japanese, the bombing of Chinese villages as well as chases and escapes, all of which create suspense. As mentioned earlier in the analysis of Eighth Route Army, Chinese TV producers in the new century started to place greater emphasis on picturing battle scenes in war dramas with the help of advanced filming techniques. While the 2005 drama can still be seen as a trial of these popular formulas, the narrative strategies and visual effects in On Taihang Mountain exhibit a greater level of maturity.

These developments can be considered a result of exposing state-run television stations to market forces and of increased internationalization of cinematic production. The governing body of China's television system has encouraged the inclusion of private producing companies in the making of revolutionary dramas with 'significant themes' since the mid-2000s. Unlike the other two dramas, which were solely created by state-run production units, On Taihang Mountain was jointly produced by an independent media company, Yanzhao Hezhong. The producers were thus more flexible 
in utilizing popular narrative forms, while still adhering to the officially endorsed values.

Meanwhile, Chinese producers working in the film and television field have successively drawn inspiration from imported Hollywood blockbusters. For representations of war, some filmmakers have adopted the narrative conventions from Spielberg's films (e.g. Saving Private Ryan, 1998), provoking thoughts on the nature of war and human existence as well as asking questions about how the war should be remembered in order to commemorate its casualties (Lee, 2015: 106). These genre conventions are also evident in On Taihang Mountain, as indicated by the character of Liu Bocheng, who values the lives of the soldiers and ceaselessly works on minimizing casualties. The director of the TV series notes that the producers wanted to acknowledge the contribution of the revolutionary masses in the Taihang Mountain region to the final victory (Li, 2016). The humanitarian care shown in this drama, together with the personalized descriptions of CCP leaders and improved visual effects, has thus turned this propaganda production into a war series attractive to audiences who enjoy watching war films and military themes. This reflects Chinese TV producers' increasing awareness of the commercially successful genre conventions and differentiated niche markets emerging in contemporary Chinese society. 


\section{Conclusion}

As a politically relevant and ideology-laden genre, Chinese state-sponsored revolutionary TV dramas are often credited with limited creative freedom and imagination. Yet the changing political and economic contexts of the market reforms since the 1990s have made it necessary to examine afresh the changes and continuities in televised representations of CCP revolutionary history. Our analysis of three statesponsored dramas has highlighted the links between their narrative patterns and the wider production context. Following broadly similar storylines, each TV drama shows itself to have been closely aligned with the respective official ideological line at the time of production. Their narrative focus has changed from adhering to the Party's leadership (late 1990s), to propagating the CCP's representing the fundamental interest of Chinese people in line with the Three Represents (early 2000s), to advocating the call for building a strong nation as part of the 'Chinese Dream' (mid-2010s). The positioning of the main characters in each drama reflects the changing attitudes of the Communist authorities toward the GMD, as well as the changing priorities in the construction of China's nationalism and patriotism at different historical periods.

Market-oriented production in the television sector has also introduced changes in content (e.g. by introducing fictional characters as points of identification for the audience) and style (e.g. by including graphic battle scenes to make the dramas more 
exciting) for recounting the revolutionary past. There is an increasing emphasis on the 'human factor' in the two later TV dramas, which show the political leadership as being concerned with the wellbeing of individuals living through the war. At the same time, more dramatic tensions and enhanced visual effects were incorporated into these two series - even more so in the latest drama, with the aim of better adapting the revolutionary narratives to mass consumption.

These findings reflect the competing ideological and commercial interests in Chinese TV production during the era of market reforms. Chinese television still serves (at least partially) as a propagandistic instrument but has also needed to meet popular demand by adopting new narrative formulas and visual techniques. Above all, any dramatic and artistic forms have been used to support the CCP's legitimacy to rule under the current political context. This complexity indicates not only the 'supremacy of ideology over art and commerce' but also 'ambivalences within the ideological apparatus of the state' (Lee, 2015: 107). That said, the Party seeks to use the logic of a liberal market economy to boost the cultural industry while simultaneously exerting control over this economic liberalization in the service of its political legitimizing strategy. The three TV programs examined in this article are based on Communist leaders and historical events, hence subject to the highest degree of scrutiny in the Chinese television system. Further studies may also consider to what extent fictional narratives of CCP revolutionary history, which are comparatively less driven by political mandates, have more leeway to 
depart from the interpretations prescribed by the Party-state and use their comparatively greater creative freedom to appeal to national audiences. Yet, it is foreseeable that the bottom-line rule of upholding the CCP leadership must be complied with even in more popular narratives.

\section{Notes}

1. We are using the English titles provided by the producers of the TV dramas, since they have already been used for international promotion. A more accurate translation of the Chinese title is 'Decisive Battles over China's Future'.

2. A case in point is the 1995 film Iron and Blood at the Kunlun Pass (Tie xue Kunlunguan), which depicts the Nationalist Army's battles with the Japanese invaders in Guangxi province. The film was produced in 1993 for celebrating the fiftieth anniversary of the end of the Anti-Japanese War. But due to 'its sympathetic portrayal of the heroic resistance of the Nationalist armies', which was at odds with the Communist authorities' requirement of downplaying Nationalist war efforts in the mid-1990s, the film was not allowed to be shown until 2005 (Chang, 2001: 151). 


\section{References}

Bai, R. (2005) 'Media Commercialization, Entertainment and the Party-State: The Political Economy of Contemporary Chinese Television Entertainment Culture', Global Media Journal 4(6): 1-54.

Brady, A.-M. (2008) Marketing Dictatorship: Propaganda and Thought Work in Contemporary China. Plymouth, UK: Rowman \& Littlefield Publishers, Inc.

Chang, J. (2001) 'The Politics of Commemoration: A Comparative Analysis of the Fiftieth-Anniversary Commemoration in Mainland China and Taiwan of the Victory in the Anti-Japanese War', pp. 136-161 in D. Lary and S. MacKinnon (eds) Scars of War: The Impact of Warfare on Modern China. Vancouver and Toronto: UBS Press.

China Broadcasting and Television Yearbook (2003). Beijing: Zhongguo Guangbo Dianshi Chubanshe.

Collins, N. and Cottey, A. (2018) Understanding Chinese Politics: An Introduction to Government in the People's Republic of China. Manchester: Manchester University Press.

Dittmer, L. (2006) ‘Taiwan as a Factor in China’s Quest for National Identity’, Journal of Contemporary China 15(49): 671-686. 
Dong, Y. (2005) 'Zhanzheng ticai ju de zhanchang sheji [How to design the battle scenes for war dramas]', Dangdai Dianshi 11: 5-7.

Gow, M. (2017) 'The Core Socialist Values of the Chinese Dream: towards a Chinese integral state', Critical Asian Studies 49(1): 92-116.

Gray, A. and Bell, E. (2013) History on Television. London and New York: Routledge.

Guo, B. (2003) 'Political Legitimacy and China's Transition', Journal of Chinese Political Science 8: 1-25.

Guo, Z. (2005) Zhongguo Guangbo Dianshishi [The History of Chinese Radio and Television]. Shanghai: Fudan University Press.

Hu, Z. (2004) 'Zai 2004 nian quanguo dianshiju ticai guihua huiyi shang de jianghua [A talk at the 2004 national TV drama planning conference]', Zhongguo Dianshi 4: $10-26$.

Jiang, Z. (2002) Jiang Zemin lun you Zhongguo tese de shehuizhuyi [Jiang Zemin talks about socialism with Chinese characteristics]. Beijing: Zhongyang Chubanshe. Keane, M. (2015) The Chinese Television Industry. London: Palgrave.

Lee, V. (2015) 'The Chinese War Film: Reframing National History in Transnational Cinema', pp. 101-115 in L. Funnell and M.-F. Yip (eds) American and ChineseLanguage Cinemas: Examining Cultural Flows. New York: Routledge.

Li, W. (2016) 'Yong zhengque de jiazhiguan zaixian geming guanghui [Representing the revolutionary legacy with correct values]', Zhongguo Dianshi 1: 40. 
Lin, G. and Wu, W. (2017) 'Chinese National Identity under Reconstruction', pp. 75-92 in L. Dittmer (ed.) Taiwan and China: Fitful Embrace. Oakland: University of California Press.

Ma, W. (2014) 'Chinese Main Melody TV Drama: Hollywoodization and Ideological Persuasion', Television and New Media 15(6): 523-537.

Mitter, R. (2020) China's Good War: How World War II Is Shaping a New Nationalism. Cambridge, MA: Belknap Press.

Mühlhahn, K. (2019) Making China Modern: From the Great Qing to Xi Jinping. Cambridge, MA: Belknap Press.

Pickering, M. (2001) Stereotyping: The Politics of Representation. Basingstoke: Palgrave.

Qian, G. (2008) ‘A Trip Down Memory Lane: Remaking and Rereading the Red Classics', pp. 157-171 in Y. Zhu, M. Keane and R. Bai (eds) TV Drama in China. Hong Kong: Hong Kong University Press.

Schram, S. (1989) The Thought of Mao Tse-tung. Cambridge: Cambridge University Press.

Schwartz, B. (1982) 'The Social Context of Commemoration : A Study in Collective Memory', Social Forces 61(2): 374-402.

Sun, W. and Zhao, Y. (2009) 'Television Culture with "Chinese Characteristics": The Politics of Compassion and Education', pp. 97-114 in G. Turner and J. Tay 
(eds) Television Studies After TV: Understanding Television in the PostBroadcast Era. London and New York: Routledge.

Tang, Z. and He, K. (2014) 'Zhongda geming lishi ticai dianshiju de fazhan yu chuangxin [The development and innovation of TV dramas with significant themes in revolution]', Dangdai Dianshi 4: 6-9.

Tong, Y. (1999) 'Cong lishi zhenshi dao yishu zaixian [From historical accuracy to artistic representations]', Dangdai Dianshi 12: 3-5.

Turner, G. (2010) Ordinary People and the Media: The Demotic Turn. London: SAGE Publications.

Wang, J. (1999) 'Tan “Zhongguo mingyun de juezhan” de chuangzuo [On the production of War of China's Fate]', Zhongguo Dianshi 10: 16-18.

Wang, Y. (2019) Chinese Television Between Propaganda and Entertainment: Socialist Traditions, Marketization and Popular TV Dramas, 1992-2017. PhD Thesis. Loughborough University.

Wen, H. (1992) 'Huihuang de lishi, huhuan dianshiju de huihuang [The glorious history calls for a boom in TV drama productions]', Dangdai Dianshi 12: 4-5.

Xinhua (2012). Xi Jinping: Jixu chaozhe Zhonghua minzu weida fuxing mubiao fenyong qianjin [Xi Jinping: To continue to advance towards the goal of the great rejuvenation of the Chinese nation]. Available at: https://china.huanqiu.com/article/9CaKrnJxYLu (Accessed: 15 March 2021). 
Xiong, Z. (2013) Dang de qunzhong luxian de xingcheng yu fazhan [The formation and development of the Party's Mass Line], Renminwang. Available at: http://theory.people.com.cn/n/2013/0722/c40531-22274416.html (Accessed: 15 March 2021).

Yang, W. (1997) 'Zongjie jingyan, zaichuang huihuang, zai quanguo zhongda geming lishi ticai chuangzuo huiyi shang de jianghua [A talk at the national conference for making the "significant themes"]', Dianshi Yanjiu 9: 8-18.

Yin, H. and Yang, D. (2004) 'Jiating gushi, richang jingyan, shenghuo xiju, zhuliu yishi: zhongguo dianshiju yishu chuantong [Family stories, living experiences and mainstream ideas: the artistic tradition of Chinese TV drama]', Xiandai Chuanbo 5: 56-64.

Zhang, H. (2009) 'Cong jiaohua dao yinghe: zhongguo geming lishi ticai dianshiju de shangyehua xushi celüe [From education to satisfaction: commercialized narrative strategies in Chinese revolution-themed TV dramas]', Xiandai Chuanbo 3: 68-70.

Zhao, Y. (2011) 'Sustaining and Contesting Revolutionary Legacies in Media and Ideology', pp. 201-236 in S. Heilmann and E. J. Perry (eds) Mao's Invisible Hand: The Political Foundations of Adaptive Governance in China. Cambridge and London: Harvard University Press. 
Zhou, G. and Ouyang, H. (2019) 'Xinshiji yilai zhongda geming lishi ticai dianshiju de meixue chuangxin [The aesthetic innovations of TV dramas with the significant revolutionary themes in the new century]', Zhongguo Dianshi 10: 25-29. 